\title{
Nicolai Jørgensgaard Graakjær: Musik i tv-reklamer - teori og analyse Frederiksberg: Samfundslitteratur. 2011.
}

\author{
Iben Have
}

MedieKultur 2012, 53, 157-160

Published by SMID | Society of Media researchers In Denmark | www.smid.dk The online version of this text can be found open access at www.mediekultur.dk

Der er med bogen Musik i tv-reklamer - teori og analyse ikke længere nogen undskyldning for ikke at inkludere musikken i udøvelse af og undervisning i medietekstanalyser af tv-reklamer - hverken for forskere, studerende eller undervisere ved universiteter, gymnasieskoler eller højskoler. Nicolai Jørgensgaard Graakjær, som beskriver musik som "tv-reklamens livline til vores opmærksomhed", har på baggrund af sin mangeårige forskning i emnet skrevet en velformidlet og bredt anvendelig bog, som præsenterer en række begreber og modeller, som ikke kun kan bruges til at beskrive og analysere musik i tv-reklamer, men også musik i andre kommunikative, audiovisuelle udtryk. Hensigten er med videnskabelig forankring at etablere en mere favnende og samlende analyseoptik, end der tidligere har været leveret om emnet. Ser man bort fra Graakjærs ph.d.-afhandling om samme emne, er dette således den første systematiske dansksprogede bog om musik i tv-reklamer, og den udfylder et hul, som længe har stået åbent i dansk medie-, kommunikations- og musikforskning. Og frem for blindt at stille sig oven på begreber og modeller fra filmmusikteorien, hvilket præger langt de fleste analyser af reklamemusik, så virker det befriende med en teori- og begrebsudvikling med et stringent blik (og øre) for denne genres egne kommunikative præmisser for musikalsk analyse.

Musik i tv-reklamer bygger på et solidt overblik over og indblik i den eksisterende forskning på området oparbejdet primært gennem Graakjærs ph.d.-afhandling Musik i tv-reklamer - en tekstanalytisk undersøgelse fra 2008. En stor del af bogens materiale har været udgivet i engelske og danske artikler og antologier, hvilket også medfører, at det i denne 
kontekst fremstår yderst gennemarbejdet med stort formidlingsmæssigt overskud og en høj grad af validitet. Bogens empiriske materiale præsenteres som 1446 førstegangsviste tv-reklamer på TV 2 fra april i årene 1992, 1996, 2000, 2004 samt alle McDonald's 211 førstegangsviste reklamer i perioden 2003-2009 på samme tv-kanal. Dertil kommer specifikt udvalgte reklamer, der anvendes som eksempelmateriale i bogen sammen med en næranalyse af en tv-reklame for McDonald's. De metodiske redegørelser for arbejdet med empirien er udeladt i denne sammenhæng. De 1446 reklamer har forfatteren behandlet i tidligere udgivelser, og det er også dette sample, der ligger til grund for denne bogs beregninger og modeller af f.eks. musikkens funktioner, forekomster etc.

Reklamen i'm lovin' it for McDonald's fra 2009 fungerer som gennemgånde case og introduceres som den impuls, der sætter hele bogen i gang, idet det er forfatterens møde med denne reklame, der danner baggrund for bogens undren og efterfølgende strukturering af indholdet. Beskrivelsen af oplevelsen den aften i marts 2009 fungerer i bogens indledning som regulær cliffhanger, da det ikke afsløres hvilken reklame eller reklamemusik, der er tale om, og da den række spørgsmål, som oplevelsen giver anledning til, opfordrende munder ud i sætningen: "Svarene på spørgsmålene optræder i løbet af bogen" (p. 10).

Imellem en kort indledning og afrunding er bogen næsten på sidetal inddelt $i$ to lige store hoveddele ud fra en overordnet skelnen mellem to analytiske perspektiver: "Musikken fra tv-reklamer" og "Musikken $i$ tv-reklamen". Hvor første del handler om forståelsen af reklame-musikkens transtekstuelle relation til anden musik, til produktet i reklamen og til andre audiovisuelle udtryk og andre typer af reklamer, handler det i den anden del om musikkens funktioner, betydninger og samspil med reklamens øvrige udtryksdimensioner $i$ selve reklamen. Det kan være vanskeligt at holde fra-i differentieringerne ude fra hinanden, hvorimod Jacob L. Meys begreber kontekst og kotekst, som Graakjær også anvender til at forklare forholdet mellem bogens to dele, er et mere velfungerende greb.

Bogens første del bygger på en kontekstforståelse, der med sin udgrænsning af receptions- og produktionsperspektiver stadig kredser forholdsvis tæt omkring medieteksten. Det er tv-reklamer som tekstlige fænomener og ikke deres sociologiske eller kulturteoretiske implikationer, der er i fokus. Bogen udviser imidlertid en stor interesse for den implicitte modtager med mange bud på mulige betydningsdannelser i relation til reklamerne, og bogen peger derfor naturligt videre mod fremtidige undersøgelser af den empiriske modtager. Der præsenteres brugbart analytisk værktøj bogen igennem, f.eks. bruges begreberne musikprodukt, placeringsmusik, produktmusik og produktfjern musik i bogens første del til at skelne mellem forskellige typer af relationer mellem reklamemusik og produkt.

Bogens anden og mere tekstnære del trækker i første kapitel (kapitel 6) især på den populærmusikvidenskabelige forskning fra Nicolas Cook, Philip Tagg og Richard Middleton. Der skelnes mellem primær og sekundær audiovisuel betydningsdannelse, hvor den første opstår i relationen mellem musikkens og billedernes strukturelle relationer, og den anden henviser til de associationer, som det audiovisuelle udtryk også giver anledning til. Philip Taggs tegntypologi, der med begreber som soniske, taktile og kinetiske anafoner, er 
et forsøg på at systematisere de associationer, musik kan give anledning til, præsenteres i forbindelse med den sekundære betydningsdannelse. Begreberne anvendes dog stort set ikke i bogens analyser, men kunne netop have været brugt til at nå længere i beskrivelserne af vampens "neutrale baggrundskarakter" eller i beskrivelsen af sound. Graakjær fremfører, at "analytisk er sound noget af det sværeste at fastholde og formidle, idet der ikke er udviklet bredt anerkendte notationssystemer", men det er netop taktile og soniske anafoner, der er i spil, når Graakjær beskriver sound'en i en tv-reklame for Fona som "en 'blød' ansats", en "metallisk" rumklang etc. Også her i bogens anden del udvikles en række analytisk anvendelige begreber og kategorier, f.eks. opdeles musikkens form i jingle, emblem, sang, melodi, groove og medley og dens funktion i tv-reklamen i produkt-og producentkarakteristik, stemningskulisse, associationsudløser, geografisk markør og 17 andre funktioner, der efterfølgende systematiseres i forhold til afsenderintention, tekstrelation og modtagereffekt.

En af bogens største fortrin er den grundige og alsidige brug af eksempler, der ikke på noget tidspunkt gør det svært at forstå, hvad teorien og begreberne skal bruges til i en analyse. Som en ekstra service til bogens brugere henvises der i bogens indledning og på dens omslag til en hjemmeside, hvor man kan se ni af de reklamevideoer fra YouTube, som bogen på forskellig vis behandler.

Der er flere måder at strukturere en vekselvirkning mellem teori og analyse på i medietekstanalyser. I Musik i tv-reklamer er der valgt varianten: et igangsættende casestudie (i'm lovin' it-reklamen) med efterfølgende teoretiske udfoldelser. Det fungerer godt, da der i teorigennemgangen løbende henvises tilbage til casen. I dette tilfælde er dette casestudie imidlertid delt op i to, således at første del af i'm lovin' it-analysen (den kontekstuelle analyse) indleder del et, mens anden del af caseanalysen (den kotekstuelle analyse) indleder del to. Det virker umiddelbart omvendt at begynde med den kontekstualiserede tekstanalyse (musikken fra tv-reklamen) og først en halv bog senere komme med de tekstnære beskrivelser af reklamens audiovisuelle relationer. Dette valg begrundes med tidsligheden i forfatterens første oplevelse af reklamen, og han angiver selv, at dette valg fremmer anskueligheden af de teoretiske perspektiver. Det gør det uden tvivl, men det sker på bekostning af anskueligheden i caseanalysen.

En konsekvens af denne strukturering er også, at bogen fungerer bedst, når man (i første omgang) læser den fra ende til anden. Herefter hjælper de 23 modeller og oversigter som pejlemærker for en mere selektiv anvendelse. Sammenhængskraften i bogens materiale er stor, og der forekommer flere krydshenvisninger med formuleringer som "det vender jeg tilbage til senere", men manglende sidetalshenvisninger eller indeks bagerst i bogen gør det svært at forfølge disse tråde.

Bogen er præget af en nysgerrighed og en stor tværfaglig viden om reklamer, musik, audiovisuel kommunikation og betydningsdannelse, og den indeholder mange interessante observationer - f.eks. mediespecifikke overvejelser over, hvorfor Alm. Brand bruger Bent Fabricius' Alley Cat anderledes som ventemusik i telefonen end i deres tv-reklame, og hvorfor der ikke er musik på deres hjemmeside. Eller konstateringen af at bankreklamer 
Book Review: Musik i tv-reklamer - teori og analyse

bliver mere musikalsk nedtonede i krisetider. Det sproglige overskud viser sig i neologismer som "Inteluenza" om den trendsættende rolle for jingler, som elektronikproducenten Intel tildeles. Graakjær har tydeligvis gjort meget ud af at nå en bred målgruppe, hvilket også viser sig i teorivalget. F.eks. er Hansjörg Paulis filmmusikteoretiske begreber om parafraserende, polariserende og kontrapunkterende musikbrug anvendt frem for Nicolas Cooks mere komplekse (men ikke nødvendigvis mere givende) teori om det samme, som Graakjær anvender i andre sammenhænge.

Iben Have

Lektor, ph.d.

Institut for Astetik og Kommunikation

Aarhus Universitet

musih@hum.au.dk 